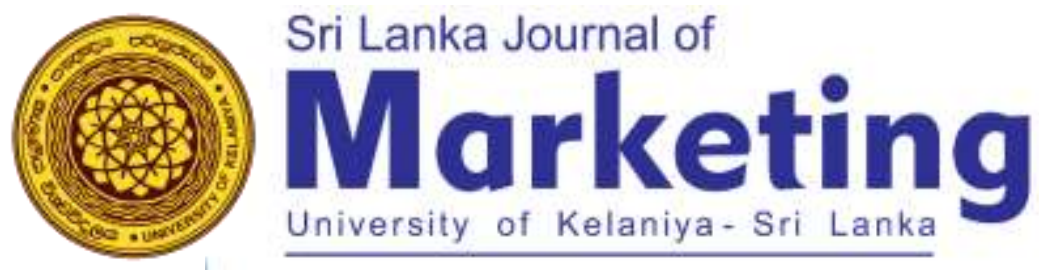

\title{
The Influence of Facebook Brand Page on Consumer Purchase Intention with Reference to Fashion Retailing Industry
}

\author{
L.B.Rajapaksha \\ University of Kelaniya, Sri Lanka \\ lahirugeo@gmail.com \\ Thilina Dk \\ Lecturer, University of Kelaniya, Sri Lanka \\ thilinasq@kln.a.clk
}

\section{ABSTRACT}

The competition in the fashion retail industry of Sri Lanka is reaching new heights due to various demands of the fashion consumers in Sri Lanka. As per the significant growth in the fashion retailing sector in Sri Lanka the marketers need to define the strategies to address their customer intentions. Especially with the rapid growth of the social networking sites especially Facebook in Sri Lanka, fashion retailers have to align their social media strategies with the online behavior of the consumers. This is study; mainly focused to understand the influence of Facebook fashion retailers' brand page and purchase intention among the Sri Lankan Face book users. Objectives of this research were to understand the influence of engaging on Facebook brand page on purchase intention for fashion retail in Sri Lanka, therefore the researcher has investigated main construct of Perceived Usefulness (PU) and Perceived Ease of Use (PEOU) of the Facebook brand page and their relationship with both Attitude towards Brand (ATB) and Purchase Intention respectively. Finally, to see whether there is a mediating effect of Attitude towards Brand on the relationship between PU and Purchase Intention and PEOU and Purchase Intension respectively. The review is based on the theoretical rationale and supportive empirical findings. A descriptive statistical review is presented to reasoning why fashion industry is considered as a context to be examined whilst empirical evidences are presented to support the arguments. The paper concludes with research propositions to examine how Facebook Brand Page make an influence on Consumer Purchase Intention.

Keywords: Facebook Brand Page, Purchase Intention, Technology Acceptance Model, Fashion Retailing 


\section{BACKGROUND OF THE STUDY}

Social media plays a vital role in present digital age. Today, consumers can use online sources to gather product information that are important for their purchase decisions. Social media has become one of the most important sources for consumers who are looking for product information and created a platform for them to share their opinions about products and brands. (Mangold \& Faulds, 2009) Suggest that social media has a vital influence over every stage of consumer decision making processes. Further (Currás-Pérez, Ruiz-Mafé, \& Sanz-Blas, 2013) argues that social networking sites such as Facebook allow users to access opinions of not only close friends, family, and colleagues but also other people who have used a particular product or service. Users also can share their content online and also exchange information with public using social media platforms. According to (Chu \& Kim, 2011), social media represent ideal tools for customers to exchange their product-related knowledge and information. Also, the customers participate in generating content which adds value to a particular brand and they might turn into advocates for the brand by sharing the content created by them.

The role of social media is not only limited to the end user, business organization also make their presence on the social media sites. Social media let firms to engage in timely and direct end-customer contact at comparatively low cost and higher levels of efficiency than can be achieved with traditional communication tools (Kaplan \& Haenlein, 2010). According to (Coulter \& Roggeveen, 2012) business organizations can use online social networks such as Facebook to create product pages, and users who follow these product pages can receive or disseminate product-related information and (Stelzner, 2013) found that $86 \%$ of marketers consider that social media channels are significant components of their marketing initiatives. Many researchers have argued that social networks are an opportunity to build even closer and more profitable relationships with customers. The company must react to this change. Companies can gain benefits by using social networks and online brand communities in their marketing: they can better understand the needs of customers and build better relationships with customers.

From the business point of view, social networking sites are more than an additional channel for disseminating information, because they let people to interact with companies and share their opinions with other users. Earlier the brands used the online brand communities to inform the consumers about the new offers or to introduce new products. However, with expansion of social media online brand communities have turn into a primary source of sharing information. It allows marketers make to twoway communication with the customers with a better scope (Thackeray, Neiger, Hanson, \& McKenzie, 2008); (Sashi C. , 2012). Therefore, company brand page administrators have to consider that their posts may influence people's online engagement and should not simply create a Facebook brand page simply because other organizations have done so. (F. Safwa Farook, 2016) It is useful for the brand to understand when customers engaged with brands to understand both positive and negative word of mouth for brand improvements. 
Due to social media becoming a strong platform for such practices, Facebook has emerged as one of the main user-friendly and intuitive platform, which allows the user to interact, connect and share (Nie, 2001); (Lesidrenska \& Dicke, 2012). Among all the social networking sites, Facebook is considered as the most popular and widely used network (Escobar-Rodríguez T. B.-F., 2017). Based on monthly active users, Facebook leads the top social networking site with more than 2 billion monthly active users on a daily basis in present-day, 684,478 pieces of content are shared on Facebook. (Kallas, 2017) Worldwide there are more than 1.5 million brand pages and the number is still growing every day and in very second social media user is following a brand. (Jeanjean, 2012)

In Sri Lankan context, there are 6.7 million internet users and 6 million social media users which has $29 \%$ of penetration compared to the total population of the country. The annual growth of Sri Lankan internet usage and social media usage in 2017 was $7 \%$ and $22 \%$ respectively. The most significant fact is that 96\% of Sri Lankan internet users are using Facebook. (Hootsuite', 2017) (MIM, 2018 ) Stated that, Sri Lanka the firms can engage in brand marketing via Facebook and create purchase intention among users.

Speaking of Facebook company pages in Sri Lanka, Facebook users visit approximately 17 pages a day, $85 \%$ of Facebook users following local brands with 35\% of them following more than 15 brands. Also a study found out that $45 \%$ of the respondents also mentioned that they're happy getting the information they need about a brand from its Facebook page without visiting its website. (Internet Usage Statistics in Sri Lanka, 2016)

\subsection{Significance of the Context}

Fashion retailing industry is one of a money-spinning as well as lively industry in the world. It stands for just about 3 trillion dollars and 2\% of the world's gross domestic product (Fashion United Group, 2017). Earlier in the 1990s, Sri Lanka was an economy of a closed market. The retail sector majorly consisted of small in private owned single stores that didn't have a corporate management and they were identified as traditional retailers (Liyanage \& Jayawardana., 2013). However, over the past years particularly after war conflicts, Sri Lankan fashion retail sector have rapidly expanded along with the development of Sri Lankan retailing sector and the amount of retailers have been amplified. The helpful macro environment has benefited domestic retailers' growth during recent years. Fashion retail industry today is at a forefront of success due to the positive macro environment changes such as post -war economic developments, growing middle class, changing consumer demands mainly due to the western cultural influences, improvement of infrastructural facilities, technological advancements etc.

As per 2013 global retail development index, Sri Lanka titled as "thriving with fresh investment ranks fifteenth with a market attractiveness of $16.6 \%$ " (Kearney, 2013). Sri Lanka's retail sector ranking according to the A.T Kearney Global Retail Development Index leap fogged to 12 in 2017 (dailynews, 
2017) and the total retail sales volume in Sri Lanka for 2016 was US\$30. In Sri Lanka’s fast growing retail sector, fashion-fashion retailing represent a large portion (39\%) showing a great possibility to develop in future (Kamburugamuwa, 2015) It reflects that fashion retail industry is an emerging sector in Sri Lanka.

This industry is considered as the industry which is perfectly suited for social media marketing (Ahmad, Salman, \& Ashiq, 2015). Therefore, in developing a brand value for fashion brands have titled their eyes towards social media marketing (Godey, 2016) However, according to (Samarasinghe, Suwandaarachchi, \& Ekanayaka, 2016) social statistics given in the site (Social Bakers), mostly the large and medium scale enterprises in apparel sector use social media as a marketing tool more than SME's. This shows that there is lack of understanding in using Facebook brand pages in Sri Lankan fashion retail context.

\subsection{Rationale of the Research Gap and Intention of the Study}

As above mentioned, Sri Lanka's retail sector ranking displays a prominent growth during recent years in terms of both sales volumes as well as the global rankings. In Sri Lanka's fast growing retail sector, fashion-fashion retailing represents a large portion of 39\% (Kamburugamuwa, 2015). This reflects the growth of the fashion retail sector in Sri Lanka.

The internet usage has grown at a significant rate of $20 \%$ to $25 \%$ every year during last 5 to 6 years in Sri Lanka. Starting from mid-2016, the amount of Facebook users in Sri Lanka amplified from 5 million to 6 million. (SoravJain, 2018) Among the 6 million Facebook users in Sri Lanka and 96\% of internet users are on Facebook. (Rathnayake \& Rathnayake, 2018) A newer and a recent local trend on Facebook were the Facebook brand communities in Sri Lanka.

However, due to the effectiveness of Facebook and its cost efficiency most of fashion-retailers still use it as a communication tool rather a strategic tool. In their study (Jayasuriya \& Azam, 2017) argue that they blindly run behind the number of likes, comments and followings without knowing the purpose of having them. There is also misuse when it comes to brand engagement. Sri Lankan Facebook pages, mainly those official pages of brands are only concerned with increasing the fan numbers and the agency or the marketer which handles it carries out Facebook advertising to increase the user growth with triggering a promotional message that easily makes the user click the like button (Insights into Sri Lankan Facebook pages: MNC and Social Bakers, 2011). This shows that there is lack of understanding in using Facebook brand pages in Sri Lankan fashion retail context. As (Jayasuriya \& Azam, 2017) Stated in his study, "furthermore, in Sri Lankan context very less amount of fashion retailers (10-15\%) have internet presence online and this amount is very less compared to other developing country like India 30\%", further explain the misuse of Facebook in Sri Lankan retail context. 
Also a significant part of the literature explains the user's intentions to join social networking sites and their attitude about them. However, there is a possibility of research in the area of customer engagement through such media and to understand the way these brand communities influence the purchase intention. The attitude towards a brand may play a vital role in decision-making for customer. This study focuses on understanding the influence of customer engagement through Facebook brand pages which affect the attitude of the customer towards the brand and in turn creates the intention to purchase the brand. There are very few studies that focus on the purchase intention initiated by the customer engagement through the brand pages of social networking sites like Facebook and this study might help the fashion retailers of Sri Lanka to understand the link and the impact of the former on the latter.

When considering the above-mentioned situation and the previous literature, intention of the current study is raised as follows.

\section{"What is the influence of Facebook brand page created on consumer purchase intention for fashion retail in Sri Lanka?”}

As per the significant growth in the fashion retailing sector in Sri Lanka the marketers need to define the strategies to address their customer intentions. Especially with the rapid growth of the social networking sites especially Facebook in Sri Lanka, fashion retailers have to align their social media strategies with the online behavior of the consumers. However, Sri Lankan fashion retailers have not understood the influence of Facebook brand page towards the attitude of Facebook users and untimely the influence on their purchase intentions. They blindly run behind the number of likes, comments and followings without knowing the purpose of having them (Jayasuriya \& Azam, 2017). Therefore, this study addresses the practical gap on how the Facebook brand page influences on the consumer purchase intention in Sri Lankan context.

Within the marketing literature, many researchers have indicated that the customer engagement in social media should be further explored through researches, despite the increased practical importance of social media and its impact on consumer engagement, particularly in the online context which encompass all social networking domains, this aspect of business marketing has been under-researched (Fournier, 2009); (Dessart, Veloutsou, \& Morgan-Thomas, 2015); (Ngai, Taoa, \& \& Moon, 2015) Islam and Rahman (2016) report that customer engagement in social network sites remains under-explored and add that customer engagement in social networking sites requires a deeper understanding. (Hajli M. , 2014) Stated that future research should take further steps to examine the role of social media on purchase intention and perceived usefulness to identify their effect. Since there is lack of studies related to understand the mediating effect of attitude toward brand on the relationship between purchase intention and brand page engagement, this study look to bridge the knowledge gap in the fashion retailing context. Also in Sri Lankan context, there are lack of studies related to Facebook brand page communities and the influence on the purchase intention within the fashion retailing sector. 
Therefore, this paper made a literature review to suggest the propositions addressing the empirical gaps and practice related knowledge requirements.

\section{METHODOLOGY}

This study has followed the literature based research approach by evaluating the existing empirical evidences. It has also taken the tested factors on given context to validate the proposed propositions for justifying the variable relationships. It has followed a mixed strategy of case reveal and literature survey as the said research notion demands a rationale on industry related perspective. This study follows a deductive approach as it brings the arguments based on existing theories and empirical evidences. Alongside, secondary sources have been used as a research tool and findings are presented as the propositions for the future studies

\section{REVIEW OF LITERATURE}

\subsection{Social Media and Online Social Networks}

As a result of the technological developments that occurred around the world, social media has flourished as a key driver of the communication and as a consequence of this, there has been groundbreaking ways of communicating among people. In the context of this study, the term, social media, according to (Dewing, 2012) "wide range of internet base services and mobile services that permit users to participate in online exchanges, contribute to user-created contents, or join online communities" including blogs (e.g., Tumblr), wikis (e.g., Wikipedia), social bookmarking (e.g., Digg), social networking sites (e.g., Facebook, Twitter, LinkedIn) and media-sharing sites (e.g., YouTube, Instagram). Social media provides platforms for users to share and to interact with others. Therefore, users' no longer using static pages and they make conversations that lead to the creation of online content. Social media applications offer the technology so that the users can create and share information through collaborative writing, sharing content (text, video, images), social networks, social bookmarking (e.g. rating, tagging) and syndication (RSS feeds), and registration with these sites free of charge (Drury, 2008).

The establishment of social media has influenced the way companies form links with their customers and the services offered by social media are not just high tech but also high-speed, effective and convenient. As users of these social media, potential customers thus engage themselves as groups with particular interests and it is this aspect of their peculiarity that allows for effortless marketing strategies (Kahle, Valette-Florence, \& Ebrary, 2012).

Within the social media platforms, social networking sites have emerged as a dynamic factor of the digital media revolution and have overcame e-mail as the most popular online activity (Nielsen, 2009). "A social networking site is a website with multiple users where a user can publish content about him/her and connect with others sharing individual or professional interests." (Goldsmith, Pagani, \& 
Lu, 2013) Social media, especially social network sites, might be a significant mean of consumer socialization because they provide a virtual space for people to communicate through connecting, producing and sharing content online. (Clemens, J.R, K, \& M, 2011); (Boyd \& Ellison, 2008). Further they act as platforms where individuals as members, construct public profiles to share their knowledge and their experiences, to post information about themselves and have get in touch with others who exchange and share alike interests. (M.K., K.O., \& Rabjohn, 2008).

These networks offer a unique opportunity for highly targeted marketing because that they are actively working with the customers and can get feedback directly from them. Therefore the businesses shouldn't ignore the opportunities to jump in and expand their customer base on these social networking sites. (Bolotaeva \& Teuta Cata, 2011) According to (Parsons, 2013) Internet marketing and social media marketing are becoming popular platforms for marketing products and services. Also many studies explained these social media and social networking sites provide opportunities via deferent means to retailers for consumer engagement and purchasing opportunities (Dessart, Veloutsou, \& MorganThomas, 2015); (Godey, 2016).

As mentioned above, number of people who are using these networks is huge and is constantly increasing and companies would want to expose their company's goods or services in front of eyes of thousands and millions and even billions of individuals who are engaged in these communities, forums, blogs or social networks. These networks are effective for influencing and tracking consumer beliefs and attitudes related to products and brands.

\subsection{Online Brand Community}

According to (Cova \& Pace., 2006), "a brand community is a collective of people with a common interest in a specific brand, creating a subculture around the brand through its own values, myths, hierarchy, rituals, and vocabulary". With the development of internet and web applications, online brand communities used to emerge from consumer initiatives but also companies have started to create communities as part of brand management strategies (Arnone, Croquet, Geerts, \& Pozniak, 2010). "Online brand community is one type of online community that can be classified based on its host: 1) consumer-initiated communities voluntarily built by their members and 2) company- initiated communities built by the companies that owns the brand in order to establish a relationship with consumers and induce productive feedback from them" (Henri \& Pudelko., 2003). Generally, online brand communities have a commercial focus and are established by marketers to achieve specific marketing goals (Muniz \& O'Guinn., 2011). The composition of brand communities has taken a further step with the introduction of online brand communities, which supports the marketing activities.

(Shang, Chen, \& Liao, 2006) Suggested that people join communities in order to learn from other customers' experiences or acquire information, and information searching has been proposed to be the main purpose for members' participation in communities. Members of online communities usually 
register using their real names and information, such as email address, telephone number etc. General activities carried out by brand community members are posting comments on discussion pages and having other daily interactions with other members (Royo-Vela \& Casamassima, 2011) and this shared information among community members significantly influence purchase intention and the brand images, according to (Park \& Cho, 2012.).

There are some studies that explain the importance of online brand community. (Cova \& Pace., 2006) Research into the online brand community of convenience product and identify the community differences from niche luxury products. (Kim, Choi, William, \& Han, 2008) Described the online brand community participants have stronger brand commitment than consumers who are not members of the community. According to (Kim, Gupta, \& Koh, 2011), among online brand community members that online community is a key influence on brand commitment and purchase intention. Further, (Goh, Heng, $\&$ Lin, 2013) indicated that engagement in such social media brand communities does have an impact on purchases.

\subsection{Facebook Brand Page}

Among all the social networking sites, Facebook is considered as the most popular and widely used network among other social media networks. (Escobar-Rodríguez T. B.-F., 2017) Based on monthly active users, Facebook leads the top social networking site with more than 2 billion monthly active users on a daily basis, 684,478 pieces of content are shared on Facebook. (Kallas, 2017) According to (Priyanka \& Srinivasan, 2015) Facebook is an important social networking website used by the firms to reach the potential customers, to inform, persuade, and remind the users about various products and services. Also (Ahmed A. I., 2016) stated that using Facebook to achieve business objectives is called Facebook marketing. For companies, social networking sites such as Facebook provide excellent platforms to engage with customers through so-called "brand pages" (Beukeboom, Kerkhof, \& de Vries, 2015). Companies can establish Facebook brand pages, which provide individuals, businesses and organizations with information that has specific purpose, audience and topic to market, promote and inform about products and services (Goorha \& Ungar, 2010). Facebook brand pages have certain features that categorize them as online communities, but also features that set them apart from traditional online communities. Companies use their Facebook brand pages to communicate with consumers and thus company representatives create a large proportion of the content. However, Facebook brand pages also enable member-initiated communication, giving the members more possibilities to create content on the page. Further, making Facebook brand pages recognizable as communities is that the members obviously share a common interest. (Gummerus, Liljander, Weman, $\&$ Pihlström, 2012). Nowadays it has become a powerful marketing communication tool for companies and organizations with more than 60 million businesses having a Facebook fan page (Hootsuite', 2017). 
Also (Pinto \& Yagnik, 2017) stated that a quarter of online social media users follow their favorite product or brand in their social network. Among them $80 \%$ of them follow the company brand pages on Facebook. Therefore, presence on Facebook makes brands discoverable and connected as well as firms can provide additional information about products or services, current promotions or events. As more and more consumers look to Facebook pages as trusted sources of information and opinions, new opportunities arise to build consumer-brand relationships and viral advertising platforms (Moran, Muzellec, \& Nolan, 2014). As (Chu \& Kim, 2011) stated, when most consumers join a brand page on Facebook, it is possible for the information that they receive from other users to influence their purchase intentions. According to (Rodríguez \& Fernández, 2017), company brand pages are fast becoming a prominent marketing channel, due to their contribution towards increasing sales. Facebook pages results in more selling opportunities for business to customer (B2C) companies.

Today users of brand pages are more experienced, and recent studies suggested further research on Facebook brand page community members (Wimmala, Mark, \& Leela, 2017). Also (Abeer \& Abdelhamid, 2017) stated that not many studies examined fan engagement and their corresponding activities and its effect on the intention to purchase a brand. Therefore, this study looks to extend the knowledge by understanding the influence of Facebook brand page engagement on shaping the attitudes of the customers and in turn affect to the purchase intention related to fashion retail sector.

\subsection{Customer Engagement in Facebook Brand Pages}

Customer engagement is defined as "behaviors go beyond transactions, and may be specifically defined as a customer's behavioral manifestations that have a brand or firm focus, beyond purchase, resulting from motivational drivers" (van Doorn, 2011). According to (Hollebeek, 2011) "customer brand engagement as the level at which the motivational, brand-related and context-dependent state of mind of a customer is expressed, in terms of a degree of activation, identification and absorption in brand interactions." Further Customer engagement has been recognized as an emotional link between a business and its customers focused on interaction with customers and their involvement.

Many studies have explained that the companies need to focus on building two-way personal relationships with customers through customer engagement. (Kumar, et al., 2010) The mere exposure effect (Zajonc, 1968) suggests that repetitive contact with and exposure to a focal brand predicts a positive attitude toward it. Many studies have argued that the key factor to customer engagement is knowledge exchange, so information and communication technologies offer vast opportunities for organizations to exchange knowledge and engage with customers. (Vivek, Beatty, \& Morgan, 2012).

In this regard, consumer engagement is an important element and it has harnessed significance over the years. This is because when there is media fragmentation due to the availability of several media choices 
there will be a decrease in consumer devotion. Businesses have to refine their marketing efforts to engage consumers as engaged consumer is emotionally connected to the brand (Sorenson, 2014).

Since 2005, there has been a spurt in the usage of the term "engagement" in the marketing literature. The increased role of social media that has created a need for the concept of customer engagement (Bielski, 2008) Also, the theoretical concept of "engagement" and "customer engagement" has been developed in online brand communities. This concept presents a working definition which defines the term engagement on online brand communities. "The term engagement can be defined as an interactive experience between the brand and customers or among the customers which comprises of cognitive, emotional or behavioral dimensions which may have online brand community consequences based on the iterative engagement process within the community or outside it." (Brodie, A, \& Biljana, 2011). Further (Libai, 2011) argued this type of customer engagement is directly related to the emergence of new media and all the new ways in which customers can interact with firms, including purchase and non-purchase behavior.

It is important to understand how engagement is related to the effectiveness of connecting to the customer in the context of online media. To understand engagement, one needs to understand the different experiences that the customers have while browsing/connecting to the site. Marketers are trying to understand, define and reinforce customer engagement while seeking to establish a relationship with customers. According to (Chetna, Pallab, \& Arun, 2016) users can engage with the brand page. The new content or update of this brand page is automatically posted to his/her personal Facebook news feed, and they can then comment on it, post on that brand page, forward offers, and contact the company and interact with other fans.

Social networking sites such as Facebook offer many options for connecting and communicating with their customers, including the brand's pages. Their highly interactive nature not only allows marketers to connect with their customers, but also allows customers to create their own communities and share and exchange information. The interactive collaboration of the organization and its problems of identification and development of solutions would play a major role.

Previous studies have also showed that the influence of Facebook brand page has impact on the user attitude formation towards the brand and the purchase intention. (Persuad, 2013) Studied controlled experiment among 96 young adults and explained the impact of interactivity and product involvement on respondents' attitudes towards brands on Facebook and their intention-to-purchase. Also (Leung \& Stahura, 2015) revealed that a positive experience with Facebook would lead to a favorable attitude towards the Facebook page, which increased the consumers' intention-to-purchase. 
According to (Sashi C. , 2012) there is a significant influence on the usage behavior of customers when it comes to online service. This influence is reflected in the customer- brand relationship, thus suggesting that there is a positive effect of integrating and engaging when Facebook brand pages are used by marketers. Previous studies show the effects of brand pages on customer behavior and also analyze the reason behind participation and other factors that may help in managing successfully (Jahn \& Kunz, 2012).

\subsection{Purchase Intention}

According to (Khan I. e., 2012), "purchase intention is an individual's intention to buy a product from a specific brand after a certain evaluation process." The main underlying concept of consumer behavior is the purchase intention which in most of the cases literature is defined as the instances which a customer is having a favorable mindset to make a transaction with the supplier or retailer. According to (Kim, Gupta, \& Koh, 2011) purchase intention is a central characteristic of consumer behavior which refers to the decision of a customer to purchase goods/services. (Ghosh, 1990) Stated during that purchase intention is an effective tool used in predicting purchasing process. Once the consumers decide to purchase the product in a certain store, they will be driven by their intention. Some researchers treat purchase intention as a base of ultimate decision. They argue that without proper purchase intention, the actual purchase is not possible because it show the likelihood behavior of a customer to make ultimate purchase (Alford and Biswas, 2000; (Wang \& Chang, 2013). (Chang, Cheung, \& Lai, 2005) Identified there are more than 80 variables as antecedents of consumer purchase intention. These were categorized as the perceived characteristics of the websites, product characteristics and customer characteristics.

A higher quality relationship between a brand and consumer leads to higher purchase intention, while positive experiences with brand, brand loyalty, and knowledge improve the quality of the brand and consumer relationship (Canniere \& Pelsmacker, 2010); (Huang, 2012); (Khan I. e., 2012). Developing quality relationships with customers is a key factor that eventually leads to customer retention. While the brand-consumer relationship is critical in forming purchase intention, consumers also consider information from other consumers as an accurate and influential source in making purchase decisions (Lee, 2009). As the Internet and technology have improved, consumers are able to access more product information before they make a purchase decision.

According to (Gaber \& Wright, 2014) purchase intention provides more proof of the efficiency rate of marketing activities and social media has a huge effect on consumer's decision-making and purchase intention. Since it is not possible to investigate all the variables that could have an effect on consumer purchase intention, this study is thus limited to investigate the effect of Facebook brand page on purchase intention. The growth of Facebook provided consumers with significant opportunities to share 
and publish information and contents about a related product or brand used. As a result, consumers have become more informative and concerned about obtaining information on product features before making any purchase (Ahmed \& Zahid, 2014) this phenomenon indicates the pertinent role of consumer engagement in Facebook brand page providing information to other users thereby, building their preferences and choices of purchase.

\subsection{Technology Acceptance Model (TAM)}

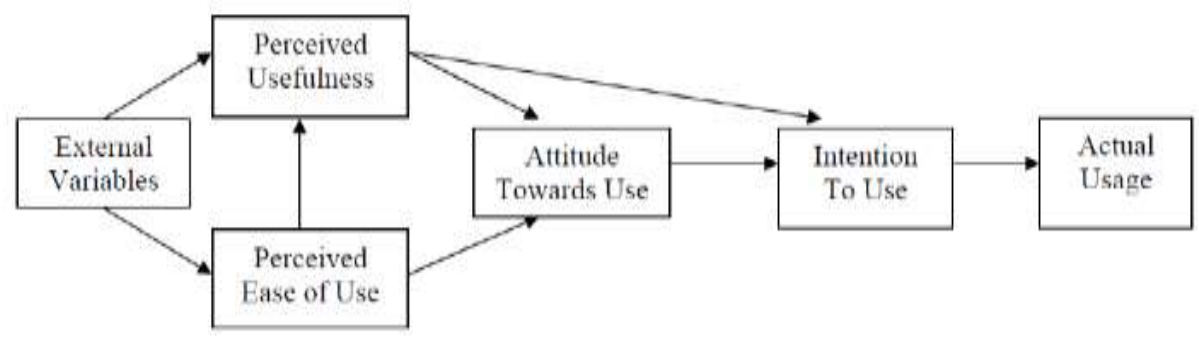

Figure 1: First Modified Version of Technology Acceptance Model (TAM) (Davis F. D., 1989)

Technology Acceptance Model (TAM) was introduced by Fred Davis in 1986 for his doctorate proposal as shown in Figure 3. An adaptation of Theory of Reasonable Action, TAM is specifically tailored for modeling users' acceptance of information systems or technologies. (Lai, 2017) In 1989, Davis used TAM to explain computer usage behavior. The goal of Davis' (1989) TAM is to explain the general determinants of computer acceptance that lead to explaining users' behavior across a broad range of end-user computing technologies and user populations. The basic TAM model included and tested two specific beliefs: Perceived Usefulness (PU) and Perceived Ease of Use (PEU). Perceived Usefulness is defined as the potential user's subjective likelihood that the use of a certain system will improve his/her action and Perceived Ease of Use refers to the degree to which the potential user expects the target system to be effortless (Davis, 1989).

The TAM was adapted from the TRA model to theorize people's usage behavior of computer technology (Davis F. D., 1989) and breaks down the TRA's attitude construct into two variables: perceived usefulness (PU) and perceived ease of use (EU) to explain computer usage behavior.

Both models have found utility for investigating consumer behavior and retailing in digital environments, such as internet shopping (Andrews \& Bianchi, 2013), social media (Chiang, 2013); (Gironda \& Korgaonkar, 2014); (Reiter, McHaney, \& Hiller, 2016) According to (Reiter, McHaney, \& Hiller, 2016), the TAM model maintains psychometric constancy when applied to social media technology use.

In the light of the significance of social media among people and the society, this topic has increasingly captured the attention of scholars (Khang, E.J., \& Ye, 2012). (Wirtz \& Göttel, 2016) Conducted a 
literature review of the TAM within the domain of social media and confirmed that "TAM is one of the most prominent models in information technology acceptance research" and "so far the prevailing theoretical approach regarding users' adoption of social media”. Lane and Coleman (2012) also confirmed the existence of a strong relationship between TAM and social networking media. Many previous studies have used the TAM to examine drivers of users' acceptance and adoption of social networking sites such as Facebook

\subsection{Attitude towards Brand and Purchase Intention}

According to (Eagly \& Chaiken, 2007) "attitude defined as a psychological path of evaluating a specific object with favor or disfavor." Some studies also explained that attitude developed through experiences may change when new experiences are obtained (Ajzen, 2001).

Considering the theory of reasoned action, (Summers, Belleau, \& Xu, 2006) observed that attitude toward performing the behavior is one of the significant predictors of purchase intention. The study further showed that purchase intention is high if a respondent's attitude toward behavior is favorable. Further Consumers' attitude becomes more favorable when relevant decision-making information is provided. This outcome confirms the positive association between attitude and intention to participate in online communities demonstrated by (Lin, 2006), confirming its validity in the case of online brand communities. Purchase intention is the most reliable pointer that builds the connection between consumer's interest and actual purchase. (Chen L. , 2014).

Studies have stated that if a consumer has a positive attitude for a brand, it significantly impacts his buying aim and his readiness to pay a premium value. Brand attitude is thought to be a marker of behavioral intentions (Wu \& Wang, 2011). The attitude of customer toward a brand has a significant effect on its purchase intention, as brand attitude is the most important determinant of purchase intention (Ahmed \& Zahid, 2014).

Further Positive and negative communications of user through social media of the companies can influence consumers' attitudes toward a particular brand. A positive attitude toward a brand influences a customer's purchase intention (Keller and Lehmann 2003).

\subsection{Perceived Usefulness (PU)}

Perceived usefulness (PU) is one of the key constructs of the technology acceptance model (TAM) (Davis F. D., 1989). Users' acceptance of computing systems was the initial developments of this theory (Davis F. D., 1989). This has been developed by many scholars in different areas related to online purchasing, social media setting etc. (Gefen et al. 2003); (Hajli M. , 2014); (Kim \& E. Ko, 2012.). TAM argues that PU construct has a strong influence in the acceptance of systems by a user (Hajli M. ,2014). 
According to previous studies, social networking sites are dynamic web based applications which can be used for customer communication and behavioral engagement (Mangold \& Faulds, 2009); (Kumar, et al., 2010). Previous studies and models like TRA (Fishbein \& Ajzen, 1975) suggests that the PU leads to behavioral intentions and recent studies also support that PU of the social media has an effect on offline behavioral intentions (Paris, Lee, \& Seery, 2010)

Previous studies explained that PU has significant influence on customer attitudes towards brand on Faccebook usage of the customers and that was also supported (Tiruwa, Yadav, \& P.K. Suri, 2016) in his study through using the TAM constructs (Moeser, Moryson, \& Schwenk, 2013)

\subsection{Perceived Ease of Use (PEOU)}

PEoU was defined as the degree to which an individual believes that by using a particular technology would be free of effort (Davis F. D., 1989). PEoU has strong influence on intention to technology acceptance as explained in TAM model. PEoU is highly relevant to behavioral intentions in online shopping accordingly to applications of the internet, which is strongly associated with intention to purchase according to many studies. (Huang, 2012); (Hongyao, 2013). And recent studies also support that PEoU of the social media has an effect on offline behavioral intentions (Moeser, Moryson, \& Schwenk, 2013).

According to earlier studies, PU and PEoU of customer engagement have direct impact on both ATB and PI in web based applications. (Mangold \& Faulds, 2009); (Moeser, Moryson, \& Schwenk, 2013). Further (Rauniar, Rawski, Yang, \& Ben, 2012); (Pinho \& Soares, 2011) stated that the significant relationship between PU and PEoU on ATB. To understand the relation between the attitude and the behavioural intention, traditional and earlier models exist, which suggest that attitude directly affects the intention. Tiruwa, Yadav, \& P.K. Suri (2016) in his study, perceived ease of use of the Facebook page has any an effect on the attitude towards the brand while customers are using and engaging with the facebook brand pages.

\section{PROPOSITIONS OF THE STUDY}

Online brand pages on social networking sites such as Facebook, being important channels for engaging customers, are finding their way in the mainstream online marketing strategy, as discussed previously. Technology acceptance model (TAM) have found utilities for investigating consumer behavior and retailing in digital environments, such as internet shopping (Andrews \& Bianchi, 2013), social media (Chiang, 2013). According to the early studies of literature in this area, the most suggestive understanding comes from the theoretical framework of TAM (Davis F. D., 1989) The TAM was adapted from the TRA model to theorize people's usage behavior of computer technology (Davis F. D., 1989) and breaks down the TRA's attitude construct into two variables: perceived usefulness (PU) and perceived ease of use (EU) to explain computer usage behavior. 
Many studies argued that TAM excluded the fact that information system could be used outside the organizational settings by individual users, and such usage can also have an "entertainment" component for the users. (Rauniar, Rawski, Yang, \& Ben, 2012); (Moeser, Moryson, \& Schwenk, 2013). Further (Escobar-Rodríguez \& Rocío Bonsón-Fernández, 2017) argued that TAM model excluded emotional and other psychosocial factors that may fully explain consumers' attitudes and behavioral intentions.

The proposed model arrests that purchase intention (PI) is determined by users perceived usefulness (PU), perceived ease of use (PEoU), and attitude towards brand (ATB). Of these constructs, two independent constructs, PU and PEOU are mediated through ATB and ATB act as a mediator influence the dependent variable PI.

Perceived Usefulness (PU): According to the TAM model, perceived usefulness (PU) is an important factor that determines an individual's intention to use a technology (Davis F. D., 1989). Also PU is defined as to how a user feels and hold perception about utilizing technology, and how it provide benefits for the user in their day-to-day tasks. (Taylor \& Todd, 1995). According to previous studies, social networking sites are dynamic web based applications which can be used for customer communication and behavioral engagement (Mangold \& Faulds, 2009; Karunanayake \& Samarasinghe, 2018); (Kozinets et al., 2010); (Kumar, et al., 2010). Previous studies and models like TRA (Fishbein $\&$ Ajzen, 1975) suggests that the PU leads to behavioral intentions and recent studies also support that PU of the social media has an effect on offline behavioral intentions (Paris, Lee, \& Seery, 2010). This leads to the following hypothesis:

\section{P1. Perceived Usefulness (PU) of customer engagement on Facebook brand page has a significant influence on Purchase Intention (PI).}

Perceived Ease of Use (PEoU): PEoU can be defined as the degree to which a user believes that a specific technology/information system is effortless to use. PEoU is highly relevant to behavioral intentions in online shopping accordingly to applications of the internet, which is strongly associated with intention to purchase according to many studies. (Huang, 2012); (Hongyao, 2013). And recent studies also support that PEoU of the social media has an effect on offline behavioral intentions (Moeser, Moryson, \& Schwenk, 2013). This leads to the following hypothesis:

\section{P2. Perceived Ease of Use (PEoU) of customer engagement on Facebook brand page has a significant influence on Purchase Intention (PI).}

The model demonstrates that perceptions of the usefulness of a technology have a major impact on its use (Venkatesh, Morris, \& Davis, 2003). Previous research findings support the concept that a user's perception of the usefulness of the interactions with a brand through social media has a positive influence on their attitude regarding that behavior (Flavian, Guinaliu, \& Gurrea, 2006); (Hernández, Jimenez, \& Martin, 2010). Also (Pinho \& Soares, 2011) stated that, the findings supported the major positive relationships between PU and attitude and also attitude and behavioral intention of usage of 
social networks. Influence on the intention of using social media and social networking based on individual's PEoU and PU which have been studied empirically in previous studies with a revised social media TAM model (Rauniar, Rawski, Yang, \& Ben, 2012). This leads to:

\section{P3. Perceived Usefulness (PU) of customer engagement on Facebook brand page has a significant} influence on Attitude towards a fashion retail brand (ATB).

Previously, PEoU has been tested empirically, and it is found to be having important effects on the attitude which in turn affect behavioral intentions (Davis F. D., 1989); (Rauniar, Rawski, Yang, \& Ben, 2012); (Moeser, Moryson, \& Schwenk, 2013). Also (Pinho \& Soares, 2011) stated that, the findings supported the major positive relationships between PU and attitude, PEOU and attitude and also attitude and behavioral intention of usage of social networks. This leads to:

P4. Perceived Ease of Use (PEoU) of customer engagement on Facebook brand page has a significant influence on Attitude towards a fashion retail Brand (ATB).

Attitude towards Brand (ATB): Attitude can be observed as, responding in a certain manner towards a situation, an object or objects favorably or unfavorably in a reliable way (Rosenberg, Hovland, McGuire, \& Brehm, 1960). Literature defines attitude toward a brand as the evaluation an individual holds for a brand, which is an antecedent to behavior (Mitchell \& Olson, 1981); (Machleit, Allen, \& Madden, 1993). According to (Davis F. D., 1989) an individual's attitude and subjective norms determine his/her behavioral intentions. . Theory of planned behavior (Ajzen \& Fishbein, 1980) is one model which directly relations attitude with intentions (Ajzen \& Fishbein, 2005) Therefore, attitudinal beliefs play a significant role when it comes to decision-making by individuals (Venkatesh, Morris, \& Davis, 2003); (Tiruwa, Yadav, \& P.K. Suri, 2016).

P5. Attitude towards a Brand has a significant influence on Purchase Intention (PI) of a fashion retail brand.

PU,PEoU, ATB and Purchase Intention (PI): According to earlier studies, PU and PEoU of customer engagement have direct impact on both ATB and PI in web based applications. (Mangold \& Faulds, 2009); (Moeser, Moryson, \& Schwenk, 2013). Further (Rauniar, Rawski, Yang, \& Ben, 2012); (Pinho \& Soares, 2011) stated that the significant relationship between PU and PEoU on ATB. To understand the relation between the attitude and the behavioral intention, traditional and earlier models exist, which suggest that attitude directly affects the intention. Theory of planned behavior (Ajzen \& Fishbein, 1980) is one model which directly relations attitude with intentions (Ajzen \& Fishbein, 2005). Other than this, earlier studies also prove that customer's intention to purchase is affected by the attitude towards a brand (Leonidou, Leonidou, \& Kvasova, 2010); (Limbu, Wolf, \& Lunsford, 2012); (Bianchi \& Andrews, 2018). 
According to above findings, the researcher assumes ATB will be positively mediating the relationships between PU, PEoU and PI. This leads to:

P6. Attitude towards Brand (ATB) mediates the effect of PU on PI.

P7. Attitude towards Brand (ATB) mediates the effect of PEoU on PI.

\section{CONCEPTUAL FRAMEWORK}

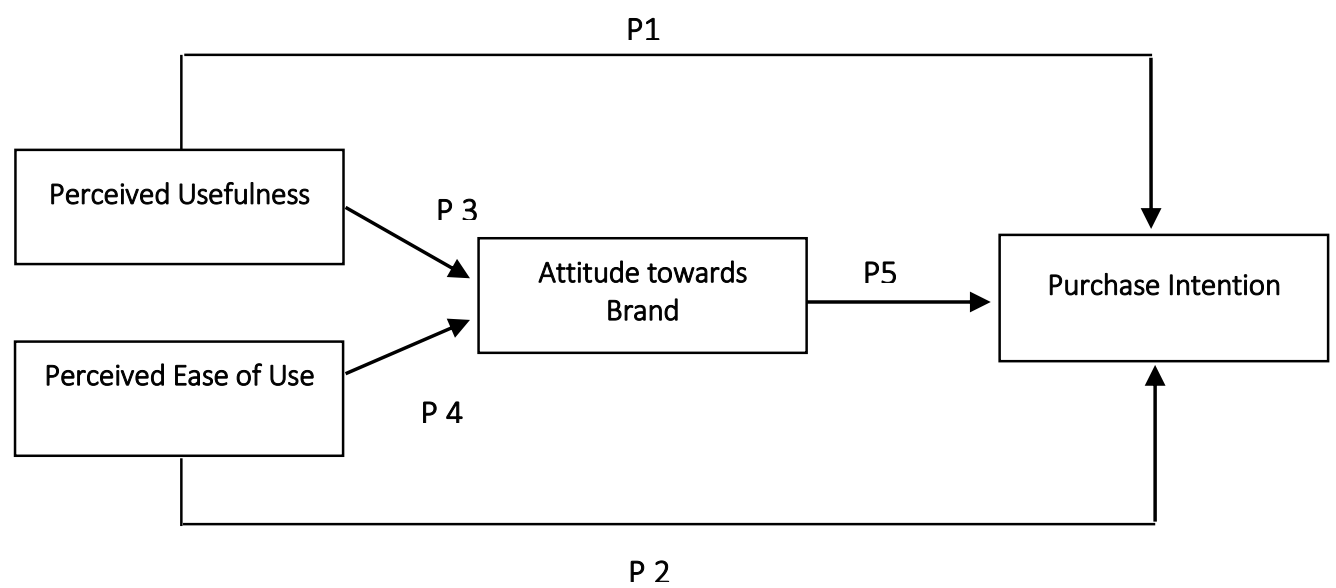

Figure 2: Conceptual Framework

Conceptual framework is the base of the entire research and framework will logically develop, described and elaborated the relationship among the variables considering to the relevant problem situation and which have been identified through literature.

\section{CONCLUSION AND FUTURE RESEARCH}

As per arguments and discussions made in this paper, suggested propositions can be conceptualized with main concepts called ‘Consumer Buying Intention' and “Facebook Brand Page Influence”. In line with this, future studies are encouraged to hypothesize how TAM variables can be adopted to measure the impact of FB brand pages on the purchase intention of customers in the context of fashion retailing industry. Researcher propose to develop hypotheses followed by deductive approach assisted by significant case issues. Moreover, it is suggested to extend the empirical studies to examine how trait factors of consumers shape the brand-related behaviors including purchase intention influenced by perceived risk factors. 


\section{REFERENCES}

[1] Abeer, A., \& Abdelhamid, A. (2017). "Antecedents of participation in online brand communities and their purchasing behavior consequences”, . Service Business, Vol. 11 No. 2, pp., 229-251.

[2] Aghakhani, N., \& Karimi, J. (2013). Acceptance of implicit and explicit eWOM: a factor based study of social networking sites.

[3] Ahmad, N., Salman, A., \& Ashiq, R. (2015). The impact of social media on fashion industry: Empirical investigation from karachiites. `. Journal of Resources Development and Management, $7,1-7$.

[4] Ahmed, A. I. (2016). Business value of Facebook: A multiple case study from a developing country. Association for InformationSystems, 8(4), , 53-68.

[5] Ahmed, M., \& Zahid, Z. (2014). Role of social media marketing to enhance CRM and brand equity in terms of purchase intention. Asian Journal of Management Research, 4(3), , 533-549.

[6] Ajzen. (2001). Nature and Operation of attitudes. Annual review of psychology 52 (1),, 27-58.

[7] Ajzen, I., \& Fishbein, M. (1980). Prentice-Hall, Englewood Cliffs, NJ.: Understanding Attitudes and Predicting Social Behavior.

[8] Ajzen, I., \& Fishbein, M. (2005). "The influence of attitudes on behavior", The Handbook of Attitudes, Vol. 173,, 221.

[9] Anderson, E. W. (1998). Customer satisfaction and word of mouth. ournal of service research, 1`(1), 5-17.

[10] Andrews, L., \& Bianchi, C. (2013). "Consumer internet purchasing behavior in Chile",. Journal of Business Research, Vol. 66 No. 10, 1791-1799.

[11] Anwar, S. K., Ramzan, N., Shoaib , M., \& Mohyuddin, A. (2015). IMPACT OF WORD OF MOUTH ON CONSUMER PURCHASE INTENTION. 27(1), 479-482.

[12] Arndt, J. (1967). Role of product-related conversations in the diffusion of a new product. Journal of marketing Research, 291-295.

[13] Arnone, L. C., Croquet, M., Geerts, A., \& Pozniak, L. (2010). "Company managed virtual communities in global brand strategy", . Global Journal of Business Research, Vol. 4 No. 2, , 97 111.

[14] Awad, N. F., \& Ragowsky, A. (2008). Establishing trust in electronic commerce through online word of mouth: An examination across genders. Journal of Management Information Systems, 24(4), 101-121.

[15] Bagozzi, R., \& Dholakia, U. (2006). Open source software user communities: A study of participation in Linux user groups. . Management science, 52, 7, 2006, , 1099-1115.

[16] Bansal, , H. S., \& Voyer, P. A. (2000). Word-of-mouth processes within a services purchase decision context. Journal of service research, 3(2), 166-177. 
[17] Barber, N. (2012). Measuring psychographics to assess purchase intention and willingness to pay. Journal of Consumer Marketing, Vol. 29, No. 4,, 147-158.

[18] Bataineh, A. Q. (2015). The Impact of Perceived e-WOM on Purchase Intention: The Mediating Role of Corporate Image. International Journal of Marketing Studies, 7(1), 126-137. doi:10.5539/ijms.v7n1p126

[19] Belaid, S., \& Temessek Behi, A. (2011). "The role of attachment in building customer-brand relationships: an empirical investigation in the utilitarian consumption context", . Journal of Product \& Brand Management, Vol. 20 No. 1, , 37-47.

[20] Berger, \& Iyengar. (2013). The Impact of Social Media On An Emerging Sport. 568.

[21] Bernoff, J., \& Li, C. (2008). Harnessing the Power of the Oh-So-Social Web. MIT Sloan Management Review, 49(3),, 36-42.

[22] Beukeboom, C., Kerkhof, P., \& de Vries, M. (2015). "Does a virtual like cause actual liking? How following a brand's Facebook updates enhances brand evaluations and purchase intention", . Journal of Interactive Marketing, Vol. 32, , 26-36.

[23] Bhayani, A. (2016). Word of mouth in consumers purchase decisions: The moderating role of product type.

[24] Bianchi, C., \& Andrews, L. (2018). "Consumer engagement with retail firms through social media: an empirical study in Chile", International. Journal of Retail \& Distribution Management, Vol. 46 Issue: 4, , 364-385.

[25] Bielski, L. (2008). "Guided by feedback: measuring customer engagement", . ABA Banking Journal, August, pp., 44-60.

[26] Blodgett, Jeffrey, G., Donald , H., Granbois, \& Rock. (1993). The effects of perceived justice on complainants' negative word-of-mouth behavior and repatronage intentions. Journal of retailing, 69(4), 399-428.

[27] Bolotaeva, V., \& Teuta Cata. (2011). Marketing Opportunities with Social Networks, . Journal of Internet Social Networking and Virtual Communities.

[28] Bone, Balk, Cerra, \& Dellinger. (1992). Definitions for sepsis and organ failure and guidelines for the use of innovative therapies in sepsis. 101(6), 1644-1655.

[29] Boyd, D. \&. (2007). Social networksites Defination,history,and Scholarship. Journal of ComputerMediated Communication, 13.

[30] Boyd, D., \& Ellison, N. (2008). Social network sites: definition, history, and scholarship. Journal of Computer-Mediated Communication, Vol. 13 No. 1, , pp. 210-230 .

[31] Breed, J. (2011). Changing the approach to customer satisfaction with social media. Retrieved from Retrieved August 26, 2015, fromhttp://hasthagsocialmedia.com/blog/change-the-approach-tocustomer-satisfaction-with social-media/:: Retrieved August 26, 2015, fromhttp://hasthagsocialmedia.com/blog/change-the-approach-to-customer-satisfaction-with social-media/. 
[32] Brodie, R., A, I., \& Biljana, J. (2011). "Consumer engagement in a virtual brand community: an exploratory analysis",. Journal of Business Research.

[33] Brown, S. P., \& Richard , F. B. (1989). Consumer complaining and word of mouth activities: field evidence. ACR North American Advances.

[34] Brown, J. J., \& Reingen, , P. H. (1987). Social ties and word-of-mouth referral behavio. Journal of Consumer research, 14(3), 350-362.

[35] Brown, J. J., \& Reingen, P. H. (1987). Social ties and word-of-mouth referral behavior. Journal of Consumer research, 14(3), 350-362.

[36] Brown, R. (2016). Restaurants, Instagram, and the Evolving Dining Experience.

[37] Burnkrant, R. E., \& Cousineau, A. (1975). Informational and Normative Social Influence in Buyer Behavior. Journal of Consumer Research, 206-215.

[38] Buttle, F. A. (1998). Word of mouth: understanding and managing referral marketing. Journal of strategic marketing, 6(3), 241-254.

[39] C, S. (2012). "Customer engagement, buyer-seller relationships, and social media",. Management Decision, Vol. 50 No. 2,, 253-272.

[40] Calder, B., Malthouse, E., \& Schaedel, U. (2009). “An experimental study of the relationship between online engagement and advertising effectiveness",. Journal of Interactive Marketing, Vol. 23 No. 4, , 321-331.

[41] Canniere, M., \& Pelsmacker, P. (2010). Relationship quality and purchase intention and behavior: The moderating impact of relationship strength. . Journal of Business Psychology, Vol. 25, 87-98.

[42] Casaló, L., Carlos Flavián, \& Guinalíu., M. (2008). "The role of perceived usability, reputation, satisfaction and consumer familiarity on the website loyalty formation process." . Computers in Human Behavior 24, no. 2, 325-345.

[43] Chang, M., Cheung, W., \& Lai, V. (2005). Literature derived reference models for the adoption of online shopping. Information \& Management, 42(4), , 543-559.

[44] Chen, L. (2014). The influence of social media on consumer behavior: An empirical study on factors influencing consumer purchase intention in China under the social media context.

[45] Chen, Y. J., \& Kirmani, A. (2011). The Consumer as Media Planner. ACR North American Advances.

[46] Chetna, K., Pallab, S., \& Arun, M. (2016). "Spreading love through fan page liking: a perspective on small scale entrepreneurs", . Computers in Human Behavior, Vol. 54, pp. , 257-270.

[47] Cheung, \& Thadani. (2012). eWOM source credibility, perceived risk and food product customer's information adoption.

[48] Cheung, C. M., Lee, M. K., \& Rabjohn, N. (2008). The impact of electronic word-of-mouth: The adoption of online opinions in online customer communities. Internet research, 18(3), 229-247. 
[49] Chiang, H. (2013). "Continuous usage of social networking sites: the effect of innovation and gratification attributes”,. Online Information Review, Vol. 37 No. 6,, 851-871.

[50] Chowdhury, N. (2016). Influence of electronic word-of-mouth on customers' purchasing decisions of tourism services in Bangladesh.

[51] Chu, C. (2011). Viral advertising in social media: Participation in Facebook groups and responses among college-aged users. Journal of Interactive Advertising, 30-43.

[52] Chu, S., \& Kim, Y. (2011). Determinants of consumer engagement in electronic. International Journal of Advertising, 47-75.

[53] Chung, J., \& Buhalis, D. (2008). Information needs in online social networks. Information Technology \& Tourism, 267-281.

[54] Chung, S. (2012). Influfence of negative and positive wom for customer reaction. Journal of environmental managemen, 92(3), 407- 418.

[55] Clemens, J.R, A., K, D. R., \& M, W. (2011). Return on Interactivity:The Impact of Online Agents on Newcomer Adjustment. Journal of Marketing, 93-108.

[56] Cong, Y., \& Zheng, Y. (2017). A Literature Review of the Influence of Electronic Word-of-Mouth on Consumer Purchase Intention. Open Journal of Business and Management, 5(3), 543.

[57] Coulter, K. S., \& Roggeveen, A. (2012). 'Like it or not': Consumer Responses to Word-of-Mouth Communication in On-Line Social Networks. Management Research Review, 878-899.

[58] Cova, B., \& Pace., S. (2006). "Brand Community of Convenience Products: New Forms of Customer Empowerment - the Case "my Nutella The Community." Edited by Len Tiu Wright. . European Journal of Marketing 40, no. 9/10, 1087-1105.

[59] Cronbach, L. J. (1951). Coefficient alpha and the internal structure of tests. Psychometrika, 16, 297-334.

[60] Curran, J., \& Lennon, R. (2011). "Participating in the conversation: exploring usage of social media networking sites”, . Academy ofMarketing Studies Journal, Vol. 15 No. 1, pp. 21-38.

[61] Currás-Pérez, R., Ruiz-Mafé, C., \& Sanz-Blas, S. (2013). Social Network Loyalty: Evaluating the Role of Attitude, Perceived Risk and Satisfaction. Online Information Review, 61-83.

[62] dailynews. (2017, $07 \quad$ 27). http://www.dailynews.lk/. Retrieved from http://www.dailynews.lk/2017/07/27/business/123337: http://www.dailynews.lk/2017/07/27/business/123337/

[63] Davis, F. (1989). Perceived usefulness, perceived ease of use, and user acceptance of information technology. 319-340.

[64] Davis, F. D. (1989). Perceived usefulness, perceived ease of use, and user acceptance of information technology. . MIS Quarterly, 13(3),, 319-340.

[65] Dellarocas, C. (2003). The digitization of word of mouth: Promise and challenges of online feedback mechanisms. Management science, 49(10), 1407- 1424. 
[66] Department of Census and Statistics Sri Lanka. (2017). Computer Literacy Statistics - 2017 (Annual). Department of Census and Statistics.

[67] Dessart, L., Veloutsou, C., \& Morgan-Thomas, A. (2015). Consumer engagement in online brand communities: A social media perspective. Journal of Product and Brand Management, 24(1), , 28 42.

[68] Dewing, M. (2012). Social media: An Introduction Parliamentary Information and Research Service. Social Affairs Division. Canada: Library of Parliament.

[69] Dichter, E. (1966). "How word-of-mouth advertising works. Harvard business review, 44(6), 147 160.

[70] Drury, G. (2008). "Social media: should marketers engage and how can it be done effectively?". Journal of Direct, Data and Digital Marketing Practice, Vol. 9 No. 3, pp. , 274-277.

[71] Duhan, D. F. (1997). Influences on consumer use of word-of-mouth recommendation sources. Journal of the academy of marketing science, 25(4), 283.

[72] Duttat, N., \& Bhat, A. K. (2017). Effect of Perceived Relational Characteristics of Online Social Network on e-WOM and Purchase Intention: Exploring Mediating Role of Trust. International Journal of Web Based Communities, 13(4). doi:10.1504/IJWBC.2017.10009147

[73] Eagly, A. H., \& Chaiken, S. (2007). "The advantages of an inclusive definition of attitude", . Social Cognition, Vol. 25 No.5, pp. 582-602.

[74] East , R., Hammond, K., \& Lomax, W. (2008). Measuring the impact of positive and negative word of mouth on brand purchase probability. International Journal of Research in Marketing, 25, 215-224. doi:10.1016/j.ijresmar.2008.04.001

[75] Escobar-Rodríguez, T. B.-F. (2017). Facebook practices for business communication among fashion retailers. Journal of Fashion Marketing and Management: An International Journal,21(1), 33-50.

[76] Escobar-Rodríguez, T., \& Rocío Bonsón-Fernández. (2017). "Facebook practices for business communication among fashion retailers", Journal of Fashion Marketing and Management: . An International Journal, Vol. 21 Issue: 1, 33-50.

[77] F. Safwa Farook, N. A. (2016). Influence of Social Media Marketing on Customer Engagement, International . Journal of Business and Management Invention, December. 2016, 115-125.

[78] Fashion United Group. (2017). Retrieved from Global Fashion Industry Statistics-International Apparel.: http://www. fashionunited.com/global-fashion-industry-statistics.

[79] Fedorikhin, A., Park, C., \& Thomson, M. (2008). "Beyond fit and attitude: the effect of emotional attachment on customer responses to brand extensions", . Journal of Customer Psychology, Vol. 8 No. 4,, 281-291.

[80] Fishbein, M., \& Ajzen, I. (1975). Belief, attitude, intention, and behavior: An introduction to theory and research. Reading, Mass; Don Mills, Ontario: Addison-Wesley Pub. Co. 
[81] Flavian, C., Guinaliu, M., \& Gurrea, R. (2006). "The role played by perceived usability, satisfaction and consumer trust on website loyalty", . Information \& Management, Vol. 43 No. 1, $1-14$.

[82] Fournier, S. \&. (2009). Getting brand communities right. Harvard Business Review, 87 (4), , $105-$ 112.

[83] Frenzen , J., \& Nakamoto, K. (1993). Structure, cooperation, and the flow of market information. 20(3), 360-375.

[84] Gabbott, \& Hogg. (2000). An empirical investigation of the impact of non-verbal communication on servicel evaluation. European Journal of Marketing, 34(3/4), 384-398.

[85] Gaber, H. R., \& Wright, L. T. (2014). Fast-food advertising in social media. A case study on Facebook in Egypt.. Journal of Business and Retail Management Research, 9(1).

[86] Ghosh, A. (1990). Retail management. Chicago: . Drydden press.

[87] Gironda, J., \& Korgaonkar, P. (2014). Journal of Marketing Management, Vol. 30 Nos 5/6,. "Understanding consumers' social networking site usage”, ,571-605.

[88] Godey, B. M. (2016). Social media marketing efforts of luxury brands: Influence on brand equity and consumer behavior. . Journal of Business Research, 69(12),, 5833-5841.

[89] Goh, K., Heng, C., \& Lin, Z. (2013). "Social media brand community and consumer behavior: quantifying the relative impact of user- and marketer-generated content", . Information Systems Research, Vol. 24 No. 1, , 88-107.

[90] Goldenberg, Jacob, Libai , B., \& Muller, E. (2001). A complex systems look at the underlying process of word-of-mouth. Marketing letters, 12(3), 211-223.

[91] Goldsmith, R. E., \& Horowitz, D. (2006). Measuring Motivations for Online Opinion Seeking. Journal of Interactive Advertising, 6(2). doi:org/10.1080/15252019.2006.10722114

[92] Goldsmith, R., Pagani, M., \& Lu, X. (2013). Social networking activity and contributing to an online review site . Interactive Marketing, Vol. 7 No. 2, 110-118.

[93] Goorha, S., \& Ungar, L. (2010). Discovery of significant emerging trends. 16th ACM SIGKDD International conference on knowledge discovery and data mining,. Washington, DC.

[94] Goyette, I., \& Ricard , L. (2010). word-of-mouth measurement scale for e-services context. Journal of Administrative Sciences/Revue Canadienne des Sciences de l'Administration, 27(1), 5-23.

[95] Gummerus, J., Liljander, V., Weman, E., \& Pihlström, E. (2012). "Customer engagement in a Facebook brand community", . Management Research Review, Vol. 35 Issue: 9, 857-877.

[96] Hair, J., Black, W., Babin, B., \& Andreson, R. (2010). Upper saddle River, New Jersey: Pearson Education International.

[97] Hajli , N. M. (2014). A study of the impact of social media on consumers. INTERNATIONAL JOURNAL OF MARKET RESEARCH, 56(3), 387-404 . doi:10.2501/IJMR-2014-025 
[98] Hajli, M. (2014). A study of the impact of social media on consumers. In te $\mathrm{rn}$ a $\mathrm{t}$ io $\mathrm{n}$ a $1 \mathrm{~J}$ o $\mathrm{u}$ rn a 1 of $\mathrm{M}$ a rk e $\mathrm{t}$ Research Vol. 56 Issue 3.

[99] Hansen , D. L., Shneiderman, B., \& Smith, M. A. (2010). Analyzing social media networks with NodeXL.

[100] Haywood, K. M. (1989). Managing word of mouth communications. Journal of Services Marketing, 3(2), 55-67.

[101] Heinrichs J.H, J.-S. L., \& Lim, K. S. (2011). Influence of social networking site. Journal of Consumer Behaviour, 347-355.

[102] Henri, F., \& Pudelko., B. (2003). "Understanding and analysing activity and learning in virtual communities." . Journal of Computer Assisted Learning 19, no. 4 (2003): , 474-487.

[103] Hernández, B., Jimenez, J., \& Martin, M. (2010). "Customer behaviour in electronic commerce: the moderating effect of e-purchasing experience”, . Journal of Business Research, Vol. 63 , 964971.

[104] Herr, P. M., Kardes , F. R., \& Kim, J. (1991). Effects of Word-of-Mouth and Product-Attribute Information on Persuasion: An Accessibility-Diagnosticity Perspective. Journal of Consumer Research, 17(4), 454-62. doi:doi.org/10.1086/208570

[105] Herr, Paul , M., Frank, R., Kardes, \& John , K. (1991). "Effects of word-of-mouth and productattribute information on persuasion: An accessibility-diagnosticity perspective. Journal of consumer research, 17(4), 454-462.

[106] Herr, Paul , Frank , \& John . (1991). Effects of word-of-mouth and product-attribute information on persuasion. Journal of consumer research, 17(4), 454-462.

[107] Hollebeek, L. (2011). "Exploring customer brand engagement: definition and themes", . Journal of Strategic Marketing, Vol. 19 No. 7, 555-573.

[108] Hongyao, N. (2013). Online Purchase Intention in B2C E-commerce: An Empirical Study. Wuhan . WHICEB 2013 Proceedings. International Conference on e-Business. Wuhan: .

[109] Hootsuite`. (2017). We are Social. Retrieved from https://hootsuite.com/pages/digital-in-2018: https://hootsuite.com/pages/digital-in-2018

[110] Horst, M., Kuttschreuter, M., \& Gutteling, J. M. (2007). Perceived usefulness, personal experiences, risk perception and trust as determinants of adoption of e-government services in The Netherlands. 23(4), 1838-1852.

[111] https://www.socialbakers.com/. (2018). Facebook Page Stats. Retrieved from https://www.socialbakers.com/statistics/facebook/pages/total/sri-lanka/place/restaurant-cafe/: https://www.socialbakers.com/statistics/facebook/pages/total/sri-lanka/place/restaurant-cafe/

[112] https://www.socialbakers.com/. (2018). Facebook Page Stats Sri Lanka. Retrieved from https://www.socialbakers.com/statistics/facebook/pages/total/sri-lanka/place/restaurant-cafe/: https://www.socialbakers.com/statistics/facebook/pages/total/sri-lanka/place/restaurant-cafe/ 
[113] Huamei. (2013). An investigation of the impact of online word of mouth on purchase intention . 2316-2319.

[114] Huang, E. (2012). Online experiences and virtual goods purchase intention. Internet Research, Vol. 22, No. 3, 252-274.

[115] Insights into Sri Lankan Facebook pages: MNC and Social Bakers. (2011). Retrieved from ft.lk: http://www.ft.lk/article/28380/Insights-into-Sri-Lankan-Facebook-pages:-MNC-and-SocialBakers

[116] Internet Usage Statistics in Sri Lanka. (2016). Retrieved from digitalmarketer.lk: http://www.digitalmarketer.lk/internet-usage-statistics-in-sri-lanka-2016-updated.html

[117] Jahn, B., \& Kunz, W. (2012). "How to transform customers into fans of your brand", . Journal of Service Management, Vol. 23 No. 3, , 344-361.

[118] Jalilvand, M. R., \& Samiei, N. (2012). The effect of electronic word of mouth on brand image and purchase intention: An empirical study in the automobile industry in Iran. Marketing Intelligence \& Planning, 30 (4), 460-476. doi:https://doi.org/10.1108/02634501211231946

[119] Jayasuriya, \& Azam. (2017). The Impact of Social Media Marketing on Brand Equity: A Study of Fashion-Wear Retail in Sri Lanka. International Review of Management and Marketing, 2017, 7(5), 178-183.

[120] Jayawardhena, C., \& Wright, L. (2009). "An empirical investigation into e-shopping excitement: antecedents and effects”, . European Journal of Marketing, Vol. 4 No. 9, pp., 1171-1187.

[121] Jeanjean, L. (2012). "5 tips to increase your Facebook fan base". Journal of Financial Planning, Vol. 1 No. 1, , 20-21.

[122] Kahle, L., Valette-Florence, P., \& Ebrary, I. (2012). Marketplace Lifestyles in an Age of Social Media: Theory and Methods. Armonk, NewYork.

[123] Kallas, P. (2017). Top 15 Most Popular Social Networking Sites and Apps. . https://www.dreamgrow.com/top-15-most-popular-social-networking-sites/ compiled the top social networking sites worldwide.

[124] Kamburugamuwa, A. (2015). Shopping Fashion Online: An Enormous Opportunity for Entrepreneurs but are we Ready Yet? Retrieved from http://www.lankabusinessonline. com/shopping-fashion-online-an-enormous-opportunity-forentrepreneurs:

http://www.lankabusinessonline. com/shopping-fashion-online-an-enormous-opportunityforentrepreneurs

[125] Kaplan, A., \& Haenlein, M. (2010). "Users of the world, unite! The challenges and opportunities of social media”. Business Horizons, Vol. 53 , 59-68.

[126] Karahanna, E., Straub, D. W., \& N Chervany, N. L. (1999). Information technology adoption across time: a cross-sectional comparison of pre-adoption and post-adoption beliefs. 183-213.

[127] Karunanayake, T., \& Samarasinghe, D. (2018). The Effect of Perceived Risk on the Purchase Intention of Alternative Fuel Vehicles. Sri Lankan Journal of Management, 23(2), 67-98. 
[128] Kassim, N., \& Asiah Abdullah, N. (2010). The effect of perceived service quality dimensions on customer satisfaction, trust, and loyalty in e-commerce settings: A cross cultural analysis. Asia Pacific Journal of Marketing and Logistics, 22(3), 351- 357.

[129] Katz, E., \& Lazarsfeld, P. F. (1955). Personal influence. New York, NY: The Free Press. .

[130] Kawakami, T., Kishiya, K., \& Parry, M. E. (2013). Personal word of mouth, virtual word of mouth, and innovation use. Journal of Product Innovation Management, 30(1), 17- 30.

[131] Kaynak, E., Kucukemiroglu, O., \& Akmal S. Hyder. (2000). Consumers' country-of-origin (COO) perceptions of imported products in a homogenous less-developed country. European Journal of Marketing, 1221-1241.

[132] Kearney, A. (2013). Global retails: Cautiously aggressive or aggressively cautious. Retrieved from [online]Available from < http://www.atkearney.com/consumer-products-retail/global-retaildevelopment-index/full-report/-/asset_publisher/oPFrGkbIkz0Q/content/2013: [online]Available from < http://www.atkearney.com/consumer-products-retail/global-retail-development-index/fullreport/-/asset_publisher/oPFrGkbIkz0Q/content/2013

[133] keller, \& Fey. (2012). An investigation of the impact of online word of mouth on purchase intention. 459.

[134] Keller, E., \& Fay, B. (2012). The face-to-face book.

[135] Khan, I. e. (2012). Impact of brand related attributes on purchase intention of customers. A study about the customer of Punjab, Pakistan. Interdisciplinary . Journal of Contemporary Research in Business, Vol. 4, No. 3, , 194-200.

[136] Khan, S. A., Ramzan, N., Shoaib, M., \& Mohyuddin. (2015). Impact of word of mouth on consumer purchase intention. 18(21), 78.

[137] Khang, H., E.J., K., \& Ye, L. (2012). "Social media research in advertising, communication, marketing, and public relations, 1997-2010",. Journalism \& Mass Communication Quarterly, Vol. 89 No. 2, 279-298.

[138] Kim, A. J., \& E. Ko. (2012.). "Do social media marketing activities enhance customer equity? An empirical study of luxury fashion brand," . Journal of Business Research, vol. 65, no. 10, , 14801486, .

[139] Kim, H. W., Gupta, S., \& Koh, J. (2011). Investigating the intention to purchase digital items in social networking communities: A customer value perspective. Information \& Management, 48(6),, 228-234.

[140] Kim, H., \& Song, J. (2010). The quality of word-of-mouth in the online shopping mall. Journal of Research in Interactive Marketing4, 4(4), 376-390.

[141] Kim, J. W., Choi, J., William, Q., \& Han, K. (2008). It takes a marketplace community to raise brand commitment: the role of online communities. . Journal of Marketing Management, 24 (3/4), , 409-431.

[142] Kline, R. (2011). Principles and practice of structural equation modling . New York: The Guilford Press. 
[143] Koh, J., \& Kim, Y. (2009). Sense of virtual community: A conceptual framework and empirical validation. . International Journal of Electronic Commerce, 8, 2, 2003, 75-93.

[144] Kolsaker, A., Lee-Kelley, L., L., \& and Choy, P. C. (2004). The reluctant Hong Kong consumer: purchasing travel online. International Journal of Consumer Studies, 28(3), 295-304.

[145] Kumar, V., Aksoy, L., Donkers, B., Venkatesan, R., Wiesel, T., \& Tillmanns, S. (2010). Undervalued or overvalued customers: capturing total customer engagement valuell . Journal of service research,Vol.13 No.3,pp., 297-310.

[146] Kunz, M., \& Hackworth, B. (2011.). Are consumers following retailers to social networks? . Academy of Marketing Studies Journal, 15 (2), 1-22.

[147] Lai, P. (2017). THE LITERATURE REVIEW OF TECHNOLOGY ADOPTION MODELS AND THEORIES FOR THE NOVELTY TECHNOLOGY. Journal of Information Systems and Technology Management.

[148] Lane, M., \& Coleman, P. (2012). "Technology ease of use through social networking media", . Journal of Technology Research, Vol. 3, 1-12.

[149] Laroche, M., Habibi, M., Richard, M., \& Sankaranarayanan, R. (2012). "The effects of social media based brand communities on brand community markers, value creation practices, brand trust and brand loyalty". Computers in Human Behavior, Vol. 28 No. 5.

[150] Lee. (2009).

[151] Leisen, B., \& Prosser, E. (2004). Customers' perception of expensiveness and its impact on loyalty behaviors. Services Marketing Quarterly, 25(3), 35-52.

[152] Leonidou, L., Leonidou, C., \& Kvasova, O. (2010). “Antecedents and outcomes of customer environmentally friendly attitudes and behavior", Journal of Marketing Management, Vol. 26 Nos $13 / 14,, 1319-1344$.

[153] Lesidrenska, S., \& Dicke, P. (2012). "Social-media platforms and its effect on digital marketing activities”, . Mapêeòèíã i ieéeäæìeíò iííoâaöié, Vol. 1 No. 2 , 44-52.

[154] Leung, X. B., \& Stahura, K. (2015). "The marketing effectiveness of social media in the hotel industry: a comparison of Facebook and Twitter", Journal of Hospitality \& Tourism Research, Vol. 39 No. 2, pp., 147-169.

[155] Liang, T.-P. H.-T.-W., \& Turban, E. (2011). What Drives Social Commerce: The Role of Social Support and Relationship. International Journal of Electronic Commerce, 69-90.

[156] Limbu, Y., Wolf, M., \& Lunsford, D. (2012). "Perceived ethics of online retailers and customer behavioral intentions: the mediating roles of trust and attitude", . Journal of Research in Interactive Marketing, Vol. 6 No. 2, , 133-154.

[157] Lin, H. (2006). "Understanding behavioral intention to participate in virtual communities", . CyberPsychology \& Behavior, Vol. 9 No. 5, pp. , 540-547.

[158] Liyanage, U., \& Jayawardana. (2013). Towards a positioning strategy for tourism in post-war Sri Lanka. . Worldwide Hospitality and Tourism Themes, 5(5),, 477-485. 
[159] Louis, D., \& Lombart, C. (2010). "Impact of brand personality on three major relational consequences (trust, attachment, and commitment to the brand)",. Journal of Product \& Brand Management, Vol. 19 No. 2, , 114-130.

[160] M.K., C. C., K.O., L. M., \& Rabjohn, N. (2008). The impact of electronic word-of-mouth: The adoption of online opinions in online customer.

[161] Machleit, K., Allen, C., \& Madden, T. (1993). "The mature brand and brand interest: an alternative consequence of ad-evoked affect”, . The Journal of Marketing, Vol. 57 No. 4, 72-82.

[162] Manap, K. A., \& Adzharudin, N. A. (2013). The role of user generated content (UGC) in social media for tourism sector. 52-58.

[163] Mangold, W. G., \& Faulds, D. J. (2009). Social media the new hybrid element of the promotion mix. Business Horizons, 357-365.

[164] Manohar, S. (2017). The mediating role of the dimensions of attitude towards advertisement and brand attitude on purchase intention. doi:10.1504/IJMDA.2017.087620

[165] Manthiou, A., \& Schrier, T. (2014). A comparison of traditional vs electronic word of mouth in the Greek hotel market: An exploratory study. Journal of Tourism Research, 8, 125-134.

[166] Maurer, C., \& Wiegmann, R. (2011). Effectiveness of advertising on social network sites: a case study on Facebook.

[167] Mazzarol, Tim, Jillian, \& Geoffrey . (2007). Conceptualizing word-of-mouth activity, triggers and conditions: an exploratory study. European Journal of Marketing, 41(12), 1475- 1494.

[168] McCormick, H., \& Livett, C. (2012). Analysing the influence of the presentation of fashion garments on young consumers' online behaviour. Journal of Fashion Marketing and Management: An International Journal, Vol. 16 Issue: 1, , pp.21-41, .

[169] MIM, H. ( 2018 ). The role of Facebook in creating E-wom and purchase intention in FMCG brand marketing in Sri Lanka. Proceedings of the Wayamba University International Conference, Sri Lanka.

[170] Mirabi, V., H., A., \& Tahmasebifard, H. .. (2015). A study of factors affecting on customers purchase intention. Journal of Multidisciplinary Engineering Science and Technology, 2(1), , 267273.

[171] Mishra, S. (2016). Casual Dining and QSR Sector Grows in Sri Lanka. New Delhi: USDA Foriegn Agricultural Services.

[172] Mitchell, A., \& Olson, J. (1981). "Are product attribute beliefs the only mediator of advertising effects on brand attitude?", Advertising \& Society Review, Vol. 1 No. 1.

[173] Moeser, G., Moryson, H., \& Schwenk, G. (2013). "Determinants of online social business network usage behavior - applying the technology acceptance model and its extensions", . Psychology, Vol. 4 No. 4,, 433. 
[174] Mollen, A., \& Wilson, H. (2010). Engagement, telepresence and interactivity in online consumer experience: Reconciling scholastic and managerial perspectives. Journal of Business Research, 63 (9-10), , 919-925, .

[175] Moran, G., Muzellec, L., \& Nolan, E. (2014). "Consumer moments of truth in the digital context". Journal of Advertising Research, Vol. 54 No. 2,, 200-204.

[176] Mordkoff, J. (2011). The Assumption(s) of Normality.

[177] Morgan, R. M., \& Hunt, ,. S. (1994). The commitment-trust theory of relationship marketing. The journal of marketing, 20-38.

[178] Muniz, J. A., \& O’Guinn., T. C. (2011). "Brand Community.” . Journal of Consumer Research 27 , no. 4, 412-432.

[179] (201). National Youth Policy Sri Lanka. Development, Ministry of Youth Affairs and Skills.

[180] Ngai, E., Taoa, S., \& \& Moon, K. (2015). Social media research: Theories, constructs, and conceptual frameworks. . International Journal of Information Management, 35(1), 33-44.

[181] Nie, N. (2001). "Sociability, interpersonal relations, and the internet reconciling conflicting findings",. American Behavioral Scientist, Vol. 45 No. 3, , 420-435.

[182] Nielsen. (2009). Nielsen online provides fastest growing social networks for September 2008.

[183] Nunnally, J. (1978). Psychometric Theory. McGraw Hill Book Company.

[184] Oppenheim, P. P. (1996). UNDERSTANDING THE FACTORS INFLUENCING CONSUMER CHOICE OF CUT FLOWERS. Proceedings of the XIII International Symposium on Horticultural Economics. doi:10.17660/ActaHortic.1996.429.52

[185] Oppenheim, P., \& Fly, T. (2000). A multinomial logit model of floral choice.

[186] Oxford Business Group. (2017). Retrieved from Retail Becomes one of Sri Lanka's FastestGrowing Sectors/Sri Lanka 2016/Oxford Business Group: https://www.oxfordbusinessgroup.com/analysis/

[187] Paris, C., Lee, W., \& Seery, P. (2010). "The role of social media in promoting special events: acceptance of Facebook 'events' ", in Gretzel, U., Law, R. and Fuchs, M. (Eds), . Information and Communication Technologies in Tourism, Springer, Vienna.

[188] Park, C., \& MacInnis, D. (2006). "What's in and what's out: questions on the boundaries of the attitude construct", . Journal of Customer Research, Vol. 33 No. 1, , 16-18.

[189] Park, H., \& Cho, H. (2012.). Social network online communities: information sources for apparel shopping. Journal of Consumer Marketing, Vol. 29 Iss. 6, pp, 400 - 411.

[190] Park, J. A., Sung, J., \& Kim, S. K. (2016). Effect of Service Quality on Revisit Intention and Word-of-Mouth at the F-1 Chinese Grand Prix. International Journal of Applied Sports Science, 28(1).

[191] Parsons, A. (2013). "Using social media to reach consumers: A content analysis of official Facebook pages,". Academy of Marketing Studies Journal, vol. 17, no. 2,. 
[192] Persuad, C. (2013). “The effects of interactivity and involvement on users' attitude toward and perception of brands and purchase intent on Facebook", . Louisiana State University, Baton Rouge, LA.

[193] Pinho, J., \& Soares, A. (2011). "Examining the technology acceptance model in the adoption of social networks", . Journal of Research in Interactive Marketing, Vol. 5 , 116-129.

[194] Pinto, M., \& Yagnik, A. (2017). Fit for life: A content analysis of fitness tracker brands use of Facebook in social media marketing. Journal of Brand Management, 24(1), , 49-67.

[195] Prendergast, Ko, \& Yeum. (2010). 690.

[196] Priyanka, P. V., \& Srinivasan, P. (2015). (2015). From a plan to generating revenue: how is social media strategy used to generate business in the retail industry in India? . International Journal of Marketing and Technology, 5(4), 62-74.

[197] Racherl, P., \& Friske, W. (2012). Perceived 'usefulness' of online consumer reviews: An exploratory investigation across three services categories. Electronic Commerce Research and Applications, 11(6), 548-559.

[198] Radwanick., S. (2010). The 2009 us digital year in review. Retrieved from www. comscore. com: http://www. comscore. com/index. php/Press_Events/Press_Releases/2010/2/comScore_Releases_2009_U. S. _Digital_Year_in_Review

[199] Rathnayake, T., \& Rathnayake, D. (2018). Facebook Usage of Sri Lankan Consumers: Consumption Perspective of Facebook. Arts and Social Sciences Journal.

[200] Rauniar, Rawski, G., Yang, J., \& Ben, J. (2012). "Technology acceptance model (TAM) and social media usage: an empirical study on Facebook", . Journal of Enterprise Information Management, Vol. 27 No. 1, 6-30.

[201] Reichelt, J., Sievert, J., \& Jacob, F. (2014). The influences of expertise, trustworthiness, and similarity on utilitarian and social functions. Journal of Marketing Communications, 20(1-2), 6581.

[202] Reiter, L., McHaney, R., \& Hiller, K. (2016). "Social media influence on purchase intentions: instrument validation”,. International Journal of Web Based Communities, Vol. 13 No. 1, 1-7.

[203] Richins, M. L. (1983). Negative word-of-mouth by dissatisfied co Negative word-of-mouth by dissatisfied consumers. The journal of marketing, 68-78.

[204] Rodríguez, T. E., \& Fernández, R. B. (2017). "Facebook practices for business communication among fashion retailers",. Journal of Fashion Marketing and Managemen An International Journal, Vol. 21 Issue: 1, , pp.33-50,.

[205] Rosenberg, M., Hovland, C., McGuire, W., \& Brehm, J. (1960). "An analysis of affectivecognitive consistency", Attitude Organization and Change: . An Analysis of Consistency Among Attitude Components, , 15-64. 
[206] Royo-Vela, M., \& Casamassima, P. (2011). The influence of belonging to virtual brand communities on consumers' affective commitment, satisfaction and word-of-mouth advertising: The ZARA case, . Online Information Review, Vol. 35 Iss. 4, pp. , $517-542$.

[207] Sahin, Sohail, M. S., \& Gokhan, O. (2010). Country-of-Origin Effects on Consumers' Evaluations of Automobiles: Perspectives from a Developing Nation. Journal of International Consumer Marketing, 245-257.

[208] Samarasinghe, G., Suwandaarachchi, C., \& Ekanayaka, E. (2016). Impact of Social Media on Business Performance:Empirical Study on Apparel Fashion Brand Retailers in Sri Lanka. NCTM.

[209] Sashi, C. (2012). "Customer engagement, buyer-seller relationships, and social media",. Management Decision, Vol. 50 No. 2., 253-272.

[210] Sashi, C. (2012). "Customer engagement, buyer-seller relationships, and social media", . Management Decision, Vol. 50 No. 2, , 253-272.

[211] Schiffman, L. G., \& Kanuk, L. L. (2010). Consumer Behaviour. Edition 10 . New Jersey: Pearson Prentice Hall.

[212] Sedley, R., \& Perks, M. (2008). Six theses on digital customer engagement in a troubled economy. Retrieved from http://richard-sedley.iuplog. com/default.asp?item=298747: http://richardsedley.iuplog. com/default.asp?item $=298747$

[213] Sekaran, U. (2003). RESEARCH METHODS FOR BUSINESS A Skill-Building Approach Fourth Edition. John Wiley \& Sons, Inc.

[214] Sen , S., \& Lerman, D. (2007). An examination into negative consumer reviews on the web. Journal of interactive marketing, 21(4), 76- 94.

[215] Shang, R., Chen, Y., \& Liao, H. (2006). The value of participation in virtual consumer communities on brand loyalty. . Internet Research, Vol. 16 Iss. 4, pp., 398 - 418.

[216] Shimp, T. (2010). Advertising, Promotion, and Other Aspects of Integrated Marketing Communications,8th ed.,. South-Western, Boston, MA: .

[217] Shin, D., \& Kim, W. (2008). "Applying the technology acceptance model and flow theory to cyworld user behavior: implication of the web 2.0 user acceptance", . Cyber Psychology and Behavior, Vol. 11 No. 3, pp. , 378-382.

[218] Silverman. (1997).

[219] Smith , D., Menon , S., \& Sivakumar, K. (2005). Online Peer and Editorial Recommendations, Trust, and Choice in Virtual Markets. Journal of Interactive Marketing, 19, 15-37. doi:https://doi.org/10.1002/dir.20041

[220] SoravJain. (2018, 04 02). https://www.soravjain.com/digital-and-social-media-marketing-statsand-facts-of-sri-lanka-2018. Retrieved from https://www.soravjain.com: https://www.soravjain.com/digital-and-social-media-marketing-stats-and-facts-of-sri-lanka-2018

[221] Sorenson, S. (2014). The Five Ways Top-Performing Companies Engage Customers. . Retrieved from http://www.gallup.com/ businessjournal/176063/five-ways-top-performing-companies- 
engage-customers.aspx : http://www.gallup.com/ businessjournal/176063/five-ways-topperforming-companies-engage-customers.aspx

[222] Stelzner, M. (2013). The 2013 Social Media Marketing Industry Report,. Social Media Examiner.

[223] Summers, T., Belleau, B., \& Xu, Y. (2006). "Predicting purchase intention of a controversial luxury apparel product", . Journal of Fashion Marketing and Management, Vol. 10 No. 4, pp. , 405419.

[224] Sussman, S. W., \& Siegal, W. S. (2003). Informational influence in organizations: An integrated approach to knowledge adoption. Information systems research, 14(1), 47-65.

[225] Taylor, S., \& Todd, P. (1995). "Understanding information technology usage: a test of competing models", . Information Systems Research, Vol. 6 No. 2, , 144-176.

[226] Thackeray, R., Neiger, B., Hanson, C., \& McKenzie, J. (2008). "Enhancing promotional strategies within social marketing programs: use of Web 2.0 social media", . Health Promotion Practice, Vol. 9 No. 4, 338-343.

[227] Thomson, M., MacInnis, D., \& Park, C. (2005). "The ties that bind: measuring the strength of customers' emotional attachments to brands", . Journal of Customer Psychology, Vol. 15 No. 1, 77 91.

[228] Thoumrungroje, A. (2014). The Influence of Social Media Intensity and EWOM on Conspicuous Consumption. Procedia - Social and Behavioral Sciences, 148, 7-15. doi:org/10.1016/j.sbspro.2014.07.009

[229] Tirunillai, \& Tellis. (2013). An investigation of the impact of online word of mouth on purchase intention. 13.

[230] Tiruwa, A., Yadav, R., \& P.K. Suri. (2016). "An exploration of online brand community (OBC) engagement and customer's intention to purchase", . Journal of Indian Business Research, Vol. 8 Issue: $4,, 295-314$.

[231] Vahl, A. (2011). Create EPIC Facebook Ads. Publication of Hubsport.

[232] van Doorn, J. (2011). "Comment: customer engagement: essence, dimensionality, and boundaries”, . Journal of Service Research, Vol. 14 No. 3, pp. 280-2.

[233] Venkatesh, V., Morris, M., \& Davis, G. (2003). "User acceptance of information technology: toward a unified view”,. MIS Quarterly, Vol. 27 No. 3, 1-54.

[234] Vivek, S., Beatty, S., \& Morgan, R. (2012). Customer engagement: exploring customer relationships beyond purchase. Journal of marketing theory and practice, Vol.20 No.2, pp.., 122146.

[235] Waad Assaad, J. M. ( September 2011 ). Social Network in marketing Opportunities and Risks. International Journal of Managing Public Sector Information and Communication Technologies Vol. 2, No. 1, 114-118.

[236] Walker, H. (2001 ). The Measurement of Word-of-Mouth Communication and an Investigation of Service Quality and Customer Commitment As Potential Antecedents. 4(1), 60- 75. 
[237] Wang, J. C., \& Chang, C. H. (2013). How online social ties and product-related risks influence purchase intentions: A Facebook experiment. . Electronic Commerce Research and Applications, 12(5),, 337-346.

[238] Wang, J., \& Senecal, S. (2007). Journal of Internet Commerce, 6(4), 97-112.

[239] Watts , D. J., \& Dodds, P. S. (2007). Influentials, Networks, and Public Opinion Formation. Journal of Consumer Research, 34(1), 441-458. doi:https://doi.org/10.1086/518527

[240] Wimmala, P., Mark, S., \& Leela, T. (2017). "Social presence and customer brand engagement on Facebook brand pages", . Journal of Product \& Brand Management, Vol. 26 No. 3, , 262-281.

[241] Wirtz, B., \& Göttel, V. (2016). "Technology acceptance in social media: review, synthesis and directions for future empirical research",. Journal of Electronic Commerce Research, Vol. 17 No. $2,, 97-115$,

[242] Wirtz, J. e. (2013). "Managing brands and customer engagement in online brand communities", . Journal of Service Management, Vol. 24 No. 3, 223-244.

[243] Wirtz, J., \& Chew, P. (2002). The effects of incentives satisfaction and tie strength on word-ofmouth behaviour. International journal of service industry management, 13(2), 141-162.

[244] Wu, P., \& Wang, Y. (2011). "The influences of electronic word-of-mouth message appeal and message source credibility on brand attitude",. Asia Pacific Journal of Marketing and Logistics, Vol. 23 No. 4, pp., 448-472.

[245] Yan, X., Shah, A. M., Zhai, L., Khan, S., \& Ali Shah, A. S. (2018). Impact of Mobile Electronic Word of Mouth (EWOM) on Consumers Purchase Intentions in the Fast-Causal Restaurant Industry in Indonesia. Hawaii International Conference on System Sciences, 3801-3810. doi:http://hdl.handle.net/10125/50367

[246] Yaylc , \& Bayram . (2012).

[247] Yusuf, A. S., Che Hussin, A. R., \& Busalim, A. H. (2018). Influence of e-WOM engagement on consumer purchase intention in social commerce. Journal of Services Marketing.

[248] Zajonc, R. (1968). "Attitudinal effects of mere exposure", . Journal of Personality and Social Psychology, Vol. 9 No. 2, pp. , 1-27.

[249] Zhang, L. L., Liu, J. X., Fang, X. Q., \& Nie, G. Q. (2014). 